\title{
Comparison of the eficacy of epidural steroid injection applied in cervical and lumbar regions
}

\author{
Servikal ve lomber bölgelere uygulanan epidural steroid enjeksiyonunun etkinliğinin \\ karşılaştırılması
}

(1) Halil ÇETINGÖK,' (1) Meltem KANAR²

\begin{abstract}
Summary
Objectives: Epidural injections have been used for many years in the treatment of chronic pain in patients with chronic backleg pain and chronic neck-arm pain. We aimed to compare the efficacy of lumbar and cervical epidural steroid injections on pain palliation, duration of pain relief and patient satisfaction.

Methods: This is a Retrospective, observational single-center study. A total of 159 patients ( 96 females, 63 males) who were performed epidural steroid injections in cervical and lumbar regions were included in the study. The patients were divided into two groups as lumbar epidural steroid injection "Group 1" and cervical epidural steroid injection "Group 2". We retrospectively evaluated the patients for numerical rating scale (NRS) prior and after the injection, the duration of the pain relief, whether any complication occured related to injection and patient satisfaction.
\end{abstract}

Results: 130 patients in Group 1 and 29 patients in Group 2 were evaluated. Median NRS before the procedure: 8 in Group 1, 7 in Group 2 and median NRS after the procedure: 3 in Group 1, 4 in group 2. Patient satisfaction with the procedure 56.15\% in Group 1 and $48.62 \%$ in Group 2. Mean duration of pain relief 7.23 months in Group 1 and 8.17 months in Group 2. There were no statistically significant difference in the evaluated parameters between the two groups.

Conclusion: It was observed that the pain relief, duration of pain relief and patient satisfaction were similar for cervical and lumbar epidural steroid injections.

Keywords: Chronic pain; clinical efficacy; epidural steroid injection; interlaminer; transforaminal.

\begin{abstract}
Özet
Amaç: Epidural enjeksiyonlar, kronik bel-bacak ağrısı ve kronik boyun-kol ağrısı olan hastalarda kronik ağrı tedavisinde uzun yıllardır kullanılmaktadır. Lomber ve servikal epidural steroid enjeksiyonlarının ağrı palyasyonu, ağıı sağaltımı süresi ve hasta memnuniyeti üzerindeki etkinliğini karşılaştırmayı amaçladık.

Gereç ve Yöntem: Bu retrospektif, gözlemsel tek merkezli bir çalışmadır. Servikal ve lomber bölgelere epidural steroid enjeksiyonu yapılan toplam 159 hasta (96 kadın, 63 erkek) çalışmaya dahil edildi. Hastalar lomber epidural steroid enjeksiyonu "Grup 1" ve servikal epidural steroid enjeksiyonu "Grup 2" olarak iki gruba ayrıldı. Hastalar enjeksiyon öncesi ve sonrası sayısal derecelendirme skalası (NRS), ağı sağaltımı süresi, enjeksiyona bağı gelişebilecek komplikasyonlar ve hasta memnuniyeti açısından geriye dönük olarak değerlendirildi.

Bulgular: Grup 1'de 130, Grup 2'de 29 hasta değerlendirildi. İşlem öncesi medyan NRS: Grup 1'de 8, Grup 2'de 7 ve işlem sonrası medyan NRS: Grup 1'de 3, Grup 2'de 4; İşlemden hasta memnuniyeti Grup 1'de \%56,15 ve Grup 2'de \%48.6; ortalama ağrı sağaltımı süresi Grup 1'de 7.23 ay ve Grup 2'de 8.17 ay idi. Her iki grupta da işleme bağlı majör komplikasyon görülmedi. Değerlendirilen parametrelerde iki grup arasında istatistiksel olarak anlamlı bir fark yoktu.

Sonuç: Servikal ve lomber epidural steroid enjeksiyonları için ağrı palyasyonu, ağrı sağaltım süresi ve hasta memnuniyetinin benzer olduğu gözlendi.
\end{abstract}

Anahtar sözcükler: Kronik ağrl; klinik etkinlik; epidural steroid enjeksiyonu; interlaminer; transforaminal.

'Division of Pain Medicine, Department of Anesthesiology, İstanbul University istanbul Faculty of Medicine, i̇stanbul, Turkey ${ }^{2}$ Division of Pain Medicine, Department of Anesthesiology, Ministry of Health Elazığ Fethi Sekin City Hospital, Elazığ, Turkey

Submitted (Başvuru tarihi) 30.12.2021 Accepted after revision (Düzeltme sonrası kabul tarihi) 02.01.2022 Available online date (Online yayımlanma tarihi) 03.01.2021

Correspondence: Dr. Halil Çetingök. İstanbul Üniversitesi İstanbul Tıp Fakültesi, Anesteziyoloji Anabilim Dalı, Algoloji Bilim Dalı, İstanbul, Turkey.

Phone: +90 - 212 - 5313147 e-mail: halilcetingok@yahoo.com

๑) 2022 Turkish Society of Algology 


\section{Introduction}

Chronic pain of spinal origin is one of the major health problems that affect the physical and psychological conditions of the patients. ${ }^{[1]}$ Supplementing conservative treatments with administration of drugs such as corticosteroids and local anesthetics to the epidural space provide significant improvements in patients' pain palliation. ${ }^{[2]}$ The aim of epidural steroid injection is to take advantage of the antiinflammatory effect of steroids which are phospholipase A2 enzyme inhibitors. In addition to the anti-inflammatory effects of steroids, they have other properties such as membrane stabilization through inhibition of ectopic impulses, inhibition of ion permeability, hyperpolarization of spinal neurons, inhibiting transmission of $C$ fibrils which can explain the relaxing effects on non-inflammatory conditions. ${ }^{[3,4]}$

In many meta-analyzes including randomized controlled trials, epidural steroid administration was considered effective in the management of chronic spinal pain, however, in some studies, it was concluded that the efficacy was not sufficient except for radicular pain due to disc herniation. ${ }^{[2,5]}$ During the first cervical epidural steroid injection was administered in 1961, the number of publications and publications supporting the efficacy of cervical epidural steroid injection is limited compared to the lumbar region. ${ }^{[6]}$ Although injections of cervical and lumbar epidural regions are performed by similar methods, these regions differ anatomically. The question arises whether the differences in the anatomical structure of these regions make a difference in the effectiveness of epidural injections.
In this study, we aimed to compare the efficacy of lumbar and cervical epidural steroid injections on pain palliation, duration of pain relief and patient satisfaction at short-term and mid-term.

\section{Material and Methods}

\section{Study Design and Setting}

Following the approval of the ethics committee, patients who were performed epidural steroid injections to the cervical or lumbar spinal canal between the dates October 2016 and January 2018, were included in the study. The study designed as retrospective observational single-center study and the information about the patients was obtained from the medical records and the patients themselves through telephone interviews at September 2018. Inclusion and exclusion criteria of the patients are shown in Table 1.

\section{Procedure}

All procedures were performed in the operating room, under aseptic conditions and under the guidance of C-arm fluoroscopy by the same experienced pain medicine specialist. Transforaminal epidural route was prefered in patients with unilateral radicular pain and imaging and clinical findings at one or two vertebral levels, and interlaminar epidural route in patients with bilateral, multiple vertebral spinal nerve level findings. Non-invasive blood pressure, pulse oximetry and electrocardiography monitoring of the patients were performed before the intervention and intravenous vascular access was obtained. Patients

Table 1. Inclusion and exclusion criteria

\begin{tabular}{ll}
\hline Inclusion criteria & Exclusion criteria \\
\hline - Adults $\geq 18$ years of age & - Severe signs of systemic infection, \\
- ASA I-II & - Local infection at the site of operation \\
- The patient has to have failed conservative treatment & - Severe neurological deficit \\
and had a cervical or lumbar epidural injection with & - Bleeding disorder \\
this indications: & - Taking medication that increased the tendency of bleeding \\
- Radiculopathy & - Pregnancy \\
- Central spinal canal stenosis & - Allergy to any of the drugs used during the procedure \\
- Neural foraminal stenosis & - Degenerative spine disease \\
- Disc pathology with imaging and clinical findings & - Facet joint syndrome \\
& - Failed back or neck surgery syndrome \\
& - Refusal to give informed consent \\
\hline
\end{tabular}


Table 2. Demographic characteristics of the patients

\begin{tabular}{|c|c|c|c|c|}
\hline & $\begin{array}{l}\text { Group } 1 \\
\text { lumbar } \\
(n=130)\end{array}$ & $\begin{array}{l}\text { Group } 2 \\
\text { cervical } \\
(n=29)\end{array}$ & $\begin{array}{c}\text { Total } \\
\begin{array}{c}\text { lumbar and cervical } \\
(n=159)\end{array}\end{array}$ & $\mathbf{p}$ \\
\hline Age (Mean \pm SD) & $52.33 \pm 13.82$ & $52.96 \pm 10.83$ & $52.45 \pm 13.29$ & $0.813^{*}$ \\
\hline \multicolumn{5}{|l|}{ Gender } \\
\hline Male & $53(40.8 \%)$ & $10(34.5 \%)$ & 63 (39.6\%) & \multirow{2}{*}{$0.531^{* *}$} \\
\hline Female & 77 (59.2\%) & 19 (65.5\%) & 96 (60.4\%) & \\
\hline \multicolumn{5}{|c|}{ The type of technique } \\
\hline Interlaminar & 10 (7.7\%) & $6(20.6 \%)$ & $16(10 \%)$ & \\
\hline Transforaminal & $120(92.3 \%)$ & 23 (79.4\%) & $143(90 \%)$ & \\
\hline
\end{tabular}

*: Mann-Whitney U test; ${ }^{* *}$ : Chi-square test; SD: Standard deviation.

were positioned supine for cervical transforaminal and prone for cervical interlaminer, lumbar interlaminer and lumbar transforaminal epidural interventions. Skin was wiped using povidone iodine-based solution and covered under aseptic conditions. Skin and subcutaneous soft tissue were anesthetized with $2 \mathrm{ml} 1 \%$ lidocaine. 1-2 mg midazolam and 50-75 $\mu \mathrm{g}$ fentanyl were used for sedation. Needle direction and depth was monitored under fluoroscopy. Contrast agent was injected $1-2 \mathrm{ml}$ in cervical and $2-3 \mathrm{ml}$ in lumbar epidural region to confirm the location of the needle and rule out dural puncture or intravascular flow. A mixture of $80 \mathrm{mg}$ triamcinolone acetate and $0.25 \%$ bupivacaine solution were injected 2 $\mathrm{ml}$ at each level for lumbar transforaminal injections and $8 \mathrm{ml}$ for lumbar interlaminar injections. A mixture of $8 \mathrm{mg}$ of dexamethasone and $0.5 \% \mathrm{li}$ docaine solution were injected $2 \mathrm{ml}$ at each level for cervical transforaminal injections and $6 \mathrm{ml}$ for cervical interlaminar injections. Patients were observed for at least four hours after injections and discharged after the absence of motor or any neurological deficit.

\section{Study Outcomes}

The numerical rating scale (NRS) (NRS; range $=0$ to 10 points; $0=$ "no pain" and $10=$ "worst pain" $)^{[7]}$ was used to evaluate pain. NRS scores of the patients before and after the procedure were obtained from the medical records. Patients were questioned on the phone for the duration of pain relief, whether any complication occured related to injection and overall satisfaction rates with epidural steroid injection procedure.

\section{Statistical Evaluation}

SPSS 21.0 (IBM Corporation, Armonk, NY) statistical program was used. Quantitative variables were expressed as means and standard deviations or as medians and interquartile range, as appropriate. Frequency was used for qualitative data. Quantitative variables were compared between groups by the Mann- Whitney $U$ test, and categorical data by the Pearson chi-square test. P-values $<0.05$ were considered to be statistically significant.

\section{Results}

A total of 159 patients ( 96 females, 63 males) who were performed epidural steroid injections of cervical and lumbar regions in due to radiculopathy, who were accesible with phone and medical records available were included in the study.

The patients were divided into two groups as lumbar epidural steroid injection Group 1 (130 patients) and cervical epidural steroid injection Group 2 (29 patients). Demographic characteristics of the patients and which technique is used (Transforaminal or Interlaminer) are shown in Table 2. There was no significant difference between the groups in terms of age and gender.

We retrospectively evaluated the patients for numerical rating scale (NRS) prior and after the injection, the duration of the pain relief, whether any complication occured related to injection and patient satisfaction. Results of the evaluation are shown in Table 3.

No significant difference was found between lumbar and cervical region in terms of pain relief as- 
Table 3. Results of the evaluation

\begin{tabular}{|c|c|c|c|c|}
\hline & $\begin{array}{l}\text { Group } 1 \\
\text { lumbar } \\
(n=130)\end{array}$ & $\begin{array}{c}\text { Group } 2 \\
\text { cervical } \\
(\mathbf{n}=29)\end{array}$ & $\begin{array}{c}\text { Total } \\
\text { Iumbar and cervical } \\
(n=159)\end{array}$ & $\mathbf{p}$ \\
\hline \multicolumn{5}{|l|}{ Pre-procedure NRS } \\
\hline Median (IQR) & $8(1)$ & $7(1)$ & $8(1)$ & $0.059^{*}$ \\
\hline Min-Max & $4-9$ & $4-9$ & $4-9$ & \\
\hline \multicolumn{5}{|l|}{ Post-procedure NRS } \\
\hline Median (IQR) & $3(3)$ & $4(4)$ & $3(3)$ & $0.298^{*}$ \\
\hline Min-Max & $0-9$ & $0-8$ & $0-9$ & \\
\hline \multicolumn{5}{|l|}{ Decrease in NRS } \\
\hline Median (IQR) & $4(3)$ & $3(4)$ & $4(3)$ & $0.064^{*}$ \\
\hline Min-Max & $0-8$ & $0-9$ & $0-9$ & \\
\hline Complications & None & None & None & $1 * *$ \\
\hline Average duration of pain relief (months) (Mean \pm SD) & $7.23 \pm 6.14$ & $8.17 \pm 8.53$ & $7.40 \pm 6.62$ & $0.979 *$ \\
\hline Satisfaction rate (\%) (Mean \pm SD) & $56.15(29.85)$ & $48.62(34.61)$ & $54.77(30.79)$ & $0.287^{*}$ \\
\hline
\end{tabular}

*: Mann-Whitney U test; ${ }^{* *}$ : Chi-square test; NRS: Numerical rating scale; SD: Standard deviation; IQR: Interquartile range; Min: Minimum; Max: Maximum.

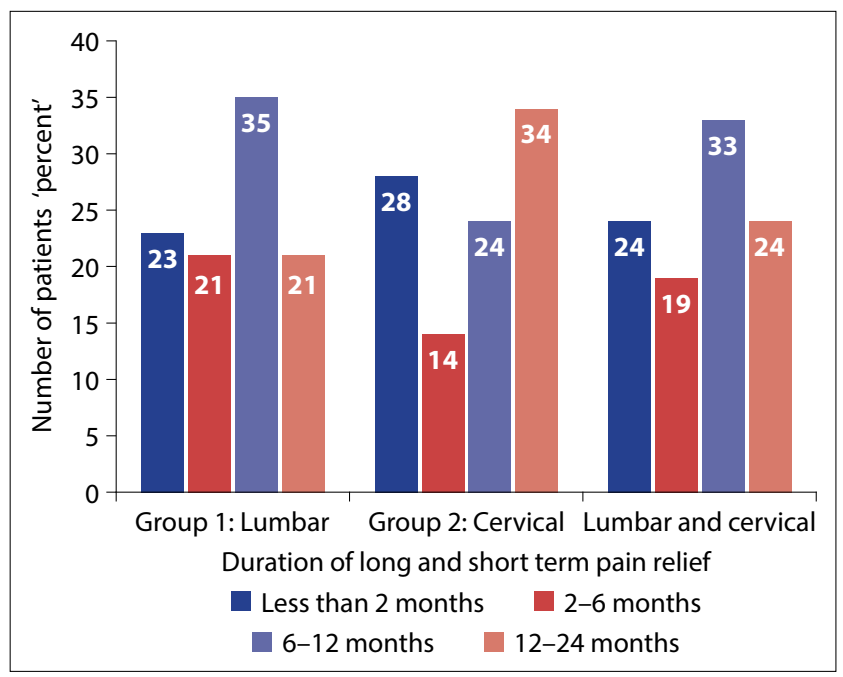

Figure 1. Duration of pain relief.

sessed by NRS scores $(p=0.064)$. There were no major complications in any of the patients.

There were no statistically significant difference between the regions in terms of satisfaction and duration of pain relief $(p=0.287, p=0.979)$ (Fig. 1, 2$)$.

\section{Discussion}

Spinal colon, vertebral structures and epidural space differ anatomically in cervical, thoracic, lumbar and sacral regions. Ligamentum flavum is quite thin in the cervical region and often does not fuse in the midline. ${ }^{[8]}$ This anatomical difference may cause no loss of resistance during injection. Epi-

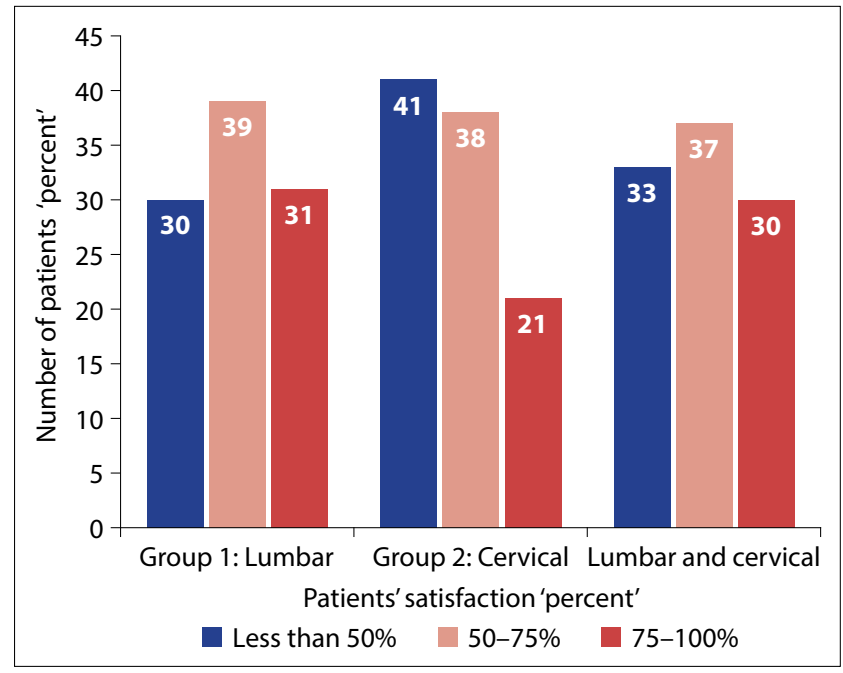

Figure 2. Patient satisfaction with epidural steroid injection.

dural distance narrows from lumbar $(5-6 \mathrm{~mm})$ to thoracic $(3-5 \mathrm{~mm})$ level and the narrowest part is at the level of C3-C6 (2 mm) cervical vertebra. ${ }^{[8]}$ The vertebral artery exits the subclavian artery and extends laterally just before the cervical spinal nerves. Vertebral artery and the radicular and medullary branches of the vertebral artery are very close to the transforaminal space and threats during transforaminal injection. ${ }^{\left[{ }^{9]}\right.}$

When the studies on cervical epidural injections are evaluated; in a retrospective study by Slipman et al., ${ }^{[10]} 20$ patients were evaluated with foraminal stenosis due to cervical spondylosis who were per- 
formed transforaminal epidural injection for radicular pain. Transforaminal epidural injection was performed on average 2.2 times and the patients' follow up period was approximately 21.2 months. They reported that VAS scores decreased from 6.9 to 2.0 and sixty percent had good and very good results. Kesikburun et al. ${ }^{[11]}$ reported that in 64 patients who were performed cervical transforaminal epidural injection, patients' VAS (visual analogue scale) scores decreased from 8.6 to 3.2 two weeks after the injection, 52 patients $(81.2 \%)$ had more than $50 \%$ pain pallation, and that the duration of treatment lasted an average of 13.3 months.

Lee et al. ${ }^{[12]}$ investigated the effect of cervical interlaminer epidural steroid injection in 45 patients with neck pain due to central cervical spinal stenosis. Neck pain evaluated by NRS was significantly reduced at 1 ., 2., and 3. months after ESI, and a successful response ( $\geq 50 \%$ pain reduction) was achieved in $58 \%$ of patients three months after the procedure, and also $56 \%$ of the patients were satisfied with the results of treatment. Kwon et al. ${ }^{[13]}$ evaluated the short-term results of 76 patients who were performed cervical interlaminar epidural steroid injections in a non-randomized study evaluating prognostic factors and reported that patients with pain due to disc herniation had better results than patients with spinal stenosis. On the other hand, Fish et al. ${ }^{[14]}$ evaluated patients with cervical radiculopathy who were performed epidural steroid injections and found that those with central canal stenosis had better functional results than those with disc herniation.

In our study; After cervical interlaminar and transforaminal epidural steroid injections, the median NRS (numerical rating scale) values of the patients decreased from 7 to 4 , the mean duration of pain relief lasted 8.17 months, and $48.62 \%$ of the patients were satisfied with the treatment. It was also observed that there were no major complications in our series. Although there are controversial and non-overlapping results regarding cervical epidural steroid injections, the decrease of nrs value to 3 is valuable and it is thought to be useful in selected patients according to our study.

When the studies on lumbar epidural injections are examined; Lutz et al. ${ }^{[15]}$ reported that $70 \%$ of patients receiving lumbar transforaminal steroids had more than $50 \%$ reduction in pain scores. In a retrospective study of Taşkaynatan et al. ${ }^{[16]} 80$ patients with low back and radicular leg pain due to lumbar disc hernia reported a $72 \%$ positive response to transforaminal epidural steroid injection and the mean duration of injection efficacy was 12 months. They also stated that there was an inverse correlation between preinjection symptom duration and duration of action and efficacy of the injection. Manchikanti et al. ${ }^{[17]}$ published a review of placebo and active controlled trials investigating the short- and long-term efficacy of caudal, interlaminary and transforaminal epidural injections for the treatment of disc herniation. In the review, the findings suggest that epidural injections reduce pain scores and improve vital functions in the short term, whereas the long-term efficacy is moderate. In addition, prospective randomized controlled study Riew et al. ${ }^{[18]}$ reported that nerve root injections reduced the rates of surgery planned for the treatment of lumbar radicular pain and that the efficacy continued during 5-year follow-up. ${ }^{[19]}$

In our study, the median NRS values of patients after lumbar epidural steroid injection decreased from 8 to 3 . The mean duration of pain relief was 7.23 months and patients were generally satisfied with the treatment and no major complications were observed. Results were similar to other studies.

There was a significant decrease in NRS scores after epidural steroid injection. Although the pain relief of epidural steroid injection and satisfaction of the lumbar region procedure were slightly higher, and the duration of pain relief in the cervical region was slightly longer, there was no statistically significant difference between the two regions in terms of pain reduction and duration of pain relief.

\section{Limitations}

The retrospective design of the study, the time of interview with patients after the procedure was not the same for each patient, the drugs used by the patients before and after the procedure are not under our control, differences of the steroid types (the use of dexamethasone in the cervical region and triamcinolone in the lumbar region) and the variety of indications (central stenosis, foraminal stenosis, radicular pain...) were the limitations of our study. 


\section{Conclusion}

Although lumbar and cervical vertebral column anatomy and accordingly epidural intervention techniques are different; The clinical effects (rate of pain relief, duration of pain relief, major complications, and patient satisfaction) of cervical and lumbar epidural injections are similar. Future randomized, controlled, prospective studies are thought to contribute positively to the guiding of cervical and lumbar epidural steroid applications.

\section{Conflict-of-interest issues regarding the authorship or article: None declared.}

Peer-rewiew: Externally peer-reviewed.

\section{References}

1. Manchikanti L, Singh V, Datta S, Cohen SP, Hirsch JA. Comprehensive review of epidemiology, scope, and impact of spinal pain. Pain Physician 2009;12(4):E35-70, [CrossRef]

2. Shim E, Lee JW, Lee E, Ahn JM, Kang Y, Kang HS. Fluoroscopically guided epidural injections of the cervical and lumbar spine. Radiographics 2017;37(2):537-61. [CrossRef]

3. Hall ED. Acute effects of intravenous glucocorticoid on cat spinal motor neuron electrical properties. Brain Res 1982;240(1):186-90. [CrossRef]

4. Johansson A, Hao J, Sjölund B. Local corticosteroid application blocks transmission in normal nociceptive C-fibres. Acta Anaesthesiol Scand 1990;34(5):335-8. [CrossRef]

5. Chou R, Hashimoto R, Friedly J, Fu R, Dana T, Sullivan S, et al. Pain management injection therapies for low back pain [Internet]. Rockville (MD): Agency for Healthcare Research and Quality; 2015.

6. Candido KD, Knezevic N.' Cervical epidural steroid injections for the treatment of cervical spinal (neck) pain. Curr Pain Headache Rep 2013;17(2):314. [CrossRef]

7. Briggs $\mathrm{M}$, Closs JS. A descriptive study of the use of visual analogue scales and verbal rating scales for the assessment of postoperative pain in orthopedic patients. J Pain Symptom Manage 1999;18(6):438-46][CrossRef]

8. Rathmell JP. Atlas of image guided intervention in regional anesthesia and pain medicine. 2nd ed. Wolters Kluwer Lippincott Williams Wilkins; 2011. p: 35.
9. Gitkind Al, Olson TR, Downie SA. Vertebral artery anatomical variations as they relate to cervical transforaminal epidural steroid injections. Pain Med 2014;15(7):1109-14 [CrossRef]

10. Slipman CW, Lipetz JS, Jackson HB, Rogers DP, Vresilovic EJ. Therapeutic selective nerve root block in the nonsurgical treatment of atraumatic cervical spondylotic radicular pain: a retrospective analysis with independent clinical review. Arch Phys Med Rehabil 2000;81(6):741-6 [CrossRef]

11. Kesikburun S, Aras B, Kelle B, Yavuz F, Yaşar E, Taşkaynatan MA. The effectiveness of cervical transforaminal epidural steroid injection for the treatment of neck pain due to cervical disc herniation: long-term results. Pain Manag 2018;8(5):321-6. [CrossRef]

12. Lee DG, Chang MC. Effect of interlaminar epidural steroid injection in patients with central cervical spinal stenosis. World Neurosurg 2018;109:e150-4 [CrossRef]

13. Kwon JW, Lee JW, Kim SH, Choi JY, Yeom JS, Kim HJ, et al. Cervical interlaminar epidural steroid injection for neck pain and cervical radiculopathy: effect and prognostic factors. Skeletal Radiol 2007;36(5):431-6 [CrossRef]

14. Fish DE, Kobayashi HW, Chang TL, Pham Q. MRI prediction of therapeutic response to epidural steroid injection in patients with cervical radiculopathy. Am J Phys Med Rehabil 2009;88(3):239-46. [CrossRef]

15. Lutz GE, Vad VB, Wisneski RJ. Fluoroscopic transforaminal lumbar epidural steroids: an outcome study. Arch Phys Med Rehabil 1998;79(11):1362-6 [CrossRef]

16. Taskaynatan MA, Tezel K, Yavuz F, Tan AK. The effectiveness of transforaminal epidural steroid injection in patients with radicular low back pain due to lumbar disc herniation two years after treatment. J Back Musculoskelet Rehabil 2015;28(3):447-51. CrossRef]

17. Manchikanti L, Benyamin RM, Falco FJ, Kaye AD, Hirsch JA. Do epidural injections provide short- and long-term relief for lumbar disc herniation? a systematic review. Clin Orthop Relat Res 2015;473(6):1940-56. [CrossRef]

18. Riew KD, Yin Y, Gilula L, Bridwell KH, Lenke LG, Lauryssen C, et al. The effect of nerve-root injections on the need for operative treatment of lumbar radicular pain. A prospective, randomized, controlled, double-blind study. J Bone Joint Surg Am 2000;82(11):1589-93,[CrossRef]

19. Riew KD, Park JB, Cho YS, Gilula L, Patel A, Lenke LG, et al. Nerve root blocks in the treatment of lumbar radicular pain. A minimum five-year follow-up. J Bone Joint Surg Am 2006;88(8):1722-5. [CrossRef] 